\title{
Undernutrition and associated risk factors among school age children in Addis Ababa, Ethiopia
}

\author{
Dawit Degarege ${ }^{1}$, Abraham Degarege $2,3^{*}$ and Abebe Animut ${ }^{2}$
}

\begin{abstract}
Background: Causes of child undernutrition are diverse and change in space and time. Investigating current determinants of undernutrition remains vital to design an effective intervention strategy. The study assessed prevalence of undernutrition and its associated factors among children living in Addis Ababa, Ethiopia.
\end{abstract}

Methods: A community based cross-sectional study was conducted in 459 school age children and their parents or caregivers living in Lideta sub-city, Addis Ababa, Ethiopia. Participants were selected using a multi-stage simple random sampling technique. Height and weight of children was measured and their parents or care givers were interviewed for factors associated with undernutrition.

Results: About 31\% ( $n=141)$ of the children were undernourished (19.6\% stunted, 15.9\% underweight). Being male, higher birth order (>2), larger family size (6-8), low meal frequency ( $\leq 3$ times) in a day prior to the survey and mud floor house were significantly associated with undernutrition. Similarly, the risk of underweight increased significantly with an increase in age, birth order, family size and also the absence of hand washing facilities. The odds of undernutrition was lower in children born to 20-30 years old mothers compared to those born to mothers younger than 20 years.

Conclusions: Undernutrition is prevalent among school age children living in Lideta sub city, Addis Ababa. Policy makers should consider school age children in their nutrition policy documents and implement screening program and intervention strategy.

Keywords: Undernutrition, Stunting, Underweight, Risk factors, Children, Addis Ababa, Ethiopia

\section{Background}

Undernutrition contributes to half of all deaths and $28 \%$ of stunting in children worldwide [1]. In the developing countries, $52 \%$ and $34-62 \%$ of the school-age children are stunted and underweight, respectively $[1,2]$. If interventions are not carried out, it is estimated that close to one billion children will be physically and mentally impaired by 2020 [3,4]. As school age is a period of physical and mental development, prolonged undernutrition in this age group impairs their growth [5]. Undernutrition could also increase the susceptibility of children to disease [6]. Despite continued prevention efforts, child

\footnotetext{
* Correspondence: abrahamdegarege@yahoo.com

${ }^{2}$ Aklilu Lemma Institute of Pathobiology, Addis Ababa University, 1176, Addis Ababa, Ethiopia

${ }^{3}$ Department of Epidemiology, Robert Stempel College of Public Health and Social Work, Florida International University, Miami, FL, USA

Full list of author information is available at the end of the article
}

undernutrition remains a major public health problem in Sub Saharan Africa, including Ethiopia [1,2,7,8].

Factors including biology, economy, culture, environment and disease contribute to undernutrition [9]. Children are most vulnerable to undernutrition due to their low dietary intake, less access to food, inequitable distribution of food within households, improper food storage and preparation, dietary taboos and infections with pathogens [1]. Child undernutrition can be mitigated through nutritional information campaigns, broader access to maternal and child health care practices and availing affordable, diverse, and nutrient-rich food [9].

The Federal Government of Ethiopia has been working to reduce undernutrition significantly through public education and providing nutritional supplements and financial support to vulnerable families. However, the risk factors of undernutrion are diverse and could potentially change in space and time. Thus, there is a need to 
determine the current nutritional status to review the pitfalls and design effective intervention strategies. This study described the prevalence of undernutrition and factors associated with the problem among school children living in Lideta Sub-City, Addis Ababa.

\section{Methods}

\section{Study area and design}

A community based cross-sectional study was conducted among school age children living in Woreda (District) 8, Lideta Sub-City, Addis Ababa, Ethiopia, in March 2014. Lideta Sub-City is one of the ten Sub-Cities in the city. Woreda 8 is one of the ten woredas in the Sub-City and comprises two Kebeles (villages), with a total population of 6,163. The woreda has two government hospitals and two health centers, in addition to private clinics. It also has one vocational and technical school, four primary schools and a kindergarten. Most of the adult males living in the woreda are employed or merchants while most adult females mothers are housewives. Members of the community differ in their ethnic background. School age children (5 to 14 years old) who lived in the sub city for at least 5 years and consented through their mothers or caregivers, participated in the study. Severely ill (i.e. not able to communicate or provide the required information due to illness) children were excluded from the study.

\section{Data collection procedures}

Based on $24 \%$ prevalence [10], 5\% significance level (alpha), 1.5 design effect and 10\% non-response rate [11], the sample size was estimated to be 462 . This size was divided proportionally between the two Kebeles. The number of households in each Kebele was then divided by the respective sample size to determine the interval between consecutive study houses. Anthropometric measurements were made for each participating child. When the number of children in a house was greater than one, a child was randomly selected using lottery method. In the absence of an eligible child in the selected household, the next house was considered.

The mother/guardian or caregiver of each participating child was interviewed for potential determinants of child nutrition status, including socio-economy, demography, environment, health related issues and age of the child using a pre-tested structured questioner. The questionnaire was first developed in English and then translated to the Amharic language. Personal hygiene (e.g. presence or absence of dirt in finger nails, frequency of bathing in a week, occasions of hand washing, cleanness of hair, cleanness of clothes) of the child and cleanliness (e.g. environmental and sanitary facilities) of the child's house were observed and documented using a checklist of items. Three medical nurses, having previous experience in similar data collection, participated in the survey.

\section{Data quality control}

Data collectors were trained in relation to the study for one day. The questionnaire was pre-tested in an area where the study was not undertaken and errors were corrected accordingly. The weight of each child was measured using a calibrated digital balance. Each day, collected information was reviewed and errors were returned to data collectors for correction. Data validity and reliability was maintained through close supervision of data collectors by the first author.

\section{Anthropometric measurement and nutritional status assessment}

Each child was instructed to stand on the center of a digital balance. The digital balance had a vertical wooden bar with plastic tap attached to it. Weight and height of each child was measured after calibrating to the nearest $0.1 \mathrm{~kg}$ and $0.1 \mathrm{~cm}$, respectively. Height was measured against a scale where a flat head piece (attached to the plastic tap at a right angle) touched the crown of the head and formed a right angle. Each child was measured while wearing light clothes after removing shoes, belt, cap or any other material that could interfere with their actual height and weight. $Z$-score was determined using the Anthro-Plus software [12]. Based on the $Z$-score, each child was grouped as undernourished or not undernourished [13]. A child was considered undernourished when either underweight (weight-for-age $Z$ score or body mass index for-age $Z$ score $<-2$ ) or stunted (height-for-age $Z$ score $<-2$ ).

\section{Data analysis}

Data were entered into excel sheet and analyzed using STATA version 11. Frequency distribution tables were used to describe socio-demographic and nutritional status of the study participants. Bivariate and multivariate logistic regression analyses were used to quantify the magnitude of association between different factors and undernutrition. The explanatory variables included in the multivariate regression model were: I. Socioeconomic and demographic characteristics of parents [age, sex, family size, parents' average monthly income, education, occupation, religion and family decision maker], II. Child characteristics and health care practices [age, sex, illness/infection status (ill or not), personal hygiene (presence or absence of dirt in children's finger nails, frequency of child bathing in a week, occasions of hand washing, cleanness of hair, cleanness of clothes), dietary intake (daily meal frequency), birth order, immunization status (immunized: yes, no), number of general breast milk feeding years], III. Environmental 
Table 1 Socio demographic characteristics of children and their families in Woreda 8, Lideta Sub-City, Addis Ababa, Ethiopia, March 2014

\begin{tabular}{|c|c|c|c|}
\hline Variable & Categories & Number of observations & Relative frequency \\
\hline \multirow[t]{4}{*}{ Marital status } & Married & 369 & 80.4 \\
\hline & Divorced & 33 & 7.2 \\
\hline & Widowed & 51 & 11.1 \\
\hline & Unmarried & 6 & 1.3 \\
\hline \multirow[t]{3}{*}{ Family size } & $2-5$ & 307 & 66.9 \\
\hline & $6-8$ & 134 & 29.2 \\
\hline & $>8$ & 18 & 3.9 \\
\hline \multirow[t]{5}{*}{ Ethnicity of mother/caregiver } & Oromo & 135 & 29.4 \\
\hline & Amhara & 129 & 28.1 \\
\hline & Tigre & 84 & 18.3 \\
\hline & Gurage & 81 & 17.7 \\
\hline & Other & 30 & 6.5 \\
\hline \multirow[t]{5}{*}{ Religion of mother/caregiver } & Orthodox & 318 & 69.9 \\
\hline & Muslim & 75 & 16.3 \\
\hline & Protestant & 36 & 7.8 \\
\hline & Catholic & 27 & 5.9 \\
\hline & Others & 3 & 0.7 \\
\hline \multirow[t]{6}{*}{ Educational status of mother/caregiver } & Cannot read and write & 51 & 11.1 \\
\hline & Can read and write only & 28 & 6.1 \\
\hline & Primary education & 191 & 41.6 \\
\hline & Secondary education & 151 & 32.9 \\
\hline & College and above & 33 & 7.2 \\
\hline & Other & 5 & 1.1 \\
\hline \multirow[t]{3}{*}{ Monthly income of the family (in Ethiopian Birr) } & $<1000$ & 54 & 11.8 \\
\hline & $1000-2000$ & 309 & 67.3 \\
\hline & $>2000$ & 96 & 20.9 \\
\hline \multirow[t]{3}{*}{ Maternal age } & $20-35$ & 267 & 58.9 \\
\hline & $36-45$ & 147 & 32.5 \\
\hline & $>45$ & 39 & 8.6 \\
\hline \multirow[t]{3}{*}{ Maternal age at child birth } & $<20$ & 78 & 16.9 \\
\hline & $20-30$ & 321 & 69.9 \\
\hline & $>30$ & 60 & 13.1 \\
\hline \multirow[t]{2}{*}{ Age of children in years } & $5-9$ & 177 & 38.6 \\
\hline & $10-14$ & 282 & 61.4 \\
\hline \multirow[t]{2}{*}{ Sex of children } & Male & 257 & 55.9 \\
\hline & Female & 202 & 44.0 \\
\hline \multirow[t]{2}{*}{ Working status of mother } & House wife & 185 & 41.0 \\
\hline & Employed & 266 & 59.0 \\
\hline
\end{tabular}

Can read and write only*: individuals who attended non-formal education.

characteristics [source of drinking water, housing conditions (presence or absence of window, nature and cleanness of the floor), availability and cleanness of sanitary facilities such as latrine, hand washing facilities near the toilet, bathing rooms, garbage disposals]. The outcome variables included in the regression model were stunting, underweight and undernutrition. A p-value less than 0.05 was considered as statistically significant. 


\section{Ethical considerations}

The study protocol was reviewed and approved by the Institutional Research Review Committee of the College of Medicine and Public Health, Debre Markos University. The objectives and protocol were discussed with the community leaders for clarification. Participation in the study was on a voluntary basis. Oral informed consent was obtained from every participant and his/her parent before conducting the survey. Privacy and confidentiality of the information was ensured. Severely malnourished children were referred to the nearest health facility and advice was given to their parents.

\section{Results}

Socio demographic characteristics

A total of 459 children (55.99\% male) and their parents or caregivers were enrolled in the study (Tables 1 and 2). Most (98\%) of the children were breastfed, among whom $14.6 \%$ and $43.8 \%$ were fed for less than 12 months and 12-24 months, respectively. Close to half of the children (49.0\%) had daily meals of greater than three times a day prior to the survey. About $61.7 \%$ and $38.3 \%$ of the children had a history of illness/infection in the year and in the two weeks prior to the study period, respectively.

\section{Undernutrition and its risk factors in school age children}

Out of the 459 children, 30.9\% were undernourished (stunted $=19.6 \%$, underweight $=15.9 \%$ ). Having a birth order greater than two, meal frequency at most three times a day, large family size (6-8), being born to a mother less than 20 years old, living in mud/soil floored house and being male were significantly associated with increased odds of undernutrition in the multivariate regression model (Table 3).

\section{Factors associated with child stunting}

The odds of stunting was significantly high in children living in a house having mud floor, birth order of $>2$, had at most 3 times daily meals, having employed and protestant or catholic mother (Table 3). Children born to mothers less than 20 years of age at the time of birth were associated with an increased risk of stunting (Table 4).

\section{Factors associated with child underweight}

Information about factors associated with children being underweight is summarized in Table 5. The likelihood of being underweight was significantly higher among children 10-14 years old than among children 5-9 years old. Children with families of 6-8 members and having no hand washing facility were more likely to be underweight compared to those with less than 6 members and having said washing facility, respectively.
Table 2 Child, maternal and environmental characteristics of in Woreda 8, Lideta Sub-City, Addis Ababa, Ethiopia, March 2014

\begin{tabular}{|c|c|c|c|}
\hline Variable & Category & $\begin{array}{l}\text { Number of } \\
\text { observations }\end{array}$ & $\begin{array}{l}\text { Relative } \\
\text { frequency }\end{array}$ \\
\hline \multirow{3}{*}{$\begin{array}{l}\text { Frequency of infection/ illness } \\
\text { in a year prior to the study } \\
\text { period } \square\end{array}$} & No illness & 102 & 22.2 \\
\hline & 1 & 114 & 24.8 \\
\hline & $>1$ & 243 & 52.9 \\
\hline \multirow{2}{*}{$\begin{array}{l}\text { Presence of illness/infection in } \\
\text { the last two week }\end{array}$} & Yes & 176 & 38.3 \\
\hline & No & 283 & 61.7 \\
\hline \multirow[t]{2}{*}{$\begin{array}{l}\text { Nature of the floor of the } \\
\text { house }\end{array}$} & $\begin{array}{l}\text { Cement/ } \\
\text { brick/ } \\
\text { ceramic }\end{array}$ & 351 & 76.5 \\
\hline & Soil & 108 & 23.5 \\
\hline \multirow[t]{2}{*}{ Presence of dirt in finger nails } & Yes & 216 & 47.1 \\
\hline & No & 243 & 52.9 \\
\hline \multirow{3}{*}{$\begin{array}{l}\text { Meal frequency in a day prior } \\
\text { to data collection }\end{array}$} & $>3$ & 225 & 49.0 \\
\hline & 3 & 177 & 38.6 \\
\hline & $<3$ & 57 & 12.4 \\
\hline \multirow{2}{*}{$\begin{array}{l}\text { Main source of power used for } \\
\text { cooking }\end{array}$} & Electric & 332 & 72.3 \\
\hline & $\begin{array}{l}\text { Wood/ } \\
\text { kerosene }\end{array}$ & 127 & 27.7 \\
\hline \multirow[t]{5}{*}{$\begin{array}{l}\text { Duration of general breast } \\
\text { feed(in months) }\end{array}$} & $\begin{array}{l}\text { Not breast } \\
\text { feed }\end{array}$ & 10 & 2.2 \\
\hline & $<12$ & 67 & 14.6 \\
\hline & $12-24$ & 201 & 43.8 \\
\hline & $>24$ & 12 & 6.4 \\
\hline & $\begin{array}{l}\text { Do not } \\
\text { remember }\end{array}$ & 60 & 13.1 \\
\hline \multirow[t]{2}{*}{ Birth order } & $\leq 2$ & 321 & 69.9 \\
\hline & $>2$ & 138 & 30.1 \\
\hline \multirow[t]{3}{*}{ Bath taking of the child } & Daily & 18 & 3.9 \\
\hline & $\begin{array}{l}\text { 2-4 times/ } \\
\text { week }\end{array}$ & 48 & 10.5 \\
\hline & Weekly & 393 & 85.6 \\
\hline \multirow{2}{*}{$\begin{array}{l}\text { Presence of hand washing } \\
\text { facility near the latrine }\end{array}$} & Yes & 177 & 39.6 \\
\hline & No & 270 & 60.4 \\
\hline \multirow{4}{*}{$\begin{array}{l}\text { Main decision maker of the } \\
\text { household }\end{array}$} & Father & 204 & 44.7 \\
\hline & Mother & 82 & 17.9 \\
\hline & $\begin{array}{l}\text { Both by } \\
\text { discussion }\end{array}$ & 138 & 30.1 \\
\hline & Not sure & 35 & 7.4 \\
\hline
\end{tabular}

$\square$ Illness/Infection: illnesses that enforces children to visit health centers/ hospitals and take medication.

\section{Discussion}

About $31 \%$ of the school age children living in Woreda 8, Lideta Sub-city, Addis Ababa in March 2014 were undernourished, among which $19.6 \%$ were stunted and $15.9 \%$ were underweight. Being male, born to a less than 20 years old mother, feeding at most 3 times a day, living 
in a mud floored house, higher $(>2)$ birth order, having large family size (6-8) and having a protestant or catholic mother were associated with undernutrition.

Undernutriton, in school age children, was reported in the forms of stunting (11\% to $42.7 \%$ ) and underweight (7.2\% to 59.7\%) in different parts of Ethiopia [14-18]. A $24 \%$ stunting was also reported in Addis Ababa [10]. The discrepancies could result from differences in the study methods and existing undernutrition programs. In addition, socio-economic differences between areas (rural vs. urban, for example) could explain the differences in the prevalence of undernutrition across Ethiopia.

Factors such as age, sex and birth order of the child were significantly associated with an increased risk of undernutrition. Undernutrition was common in children who were male, 10 to 14 years old with birth order greater than two. This is in agreement with the studies in different African countries, including Ethiopia [3,15,19-23]. Feeding practices, care and exposure to infection, which primarily determine the nutritional status of children, vary with age $[24,25]$. Children of age 10 to 14 years are more active and lose a greater amount of energy. Excess energy loss, together with lack of nutritious food, could make them undernourished. Indeed, it was the underweight children (compared to those that were overweight) who demonstrated a high level of physical activity [26]. This may have important public health implications to countries like Ethiopia which require a strategy to keep the energy balacne. Biological factors, inequalities in resource allocation within households and socio-cultural norms prevailing in the community could be responsible for the variation in the risk of undernutrition between males and females [14,27].

Table 3 Factors associated with undernutrition among school age children in Woreda 8, Lideta Sub-City, Addis Ababa, March, 2014

\begin{tabular}{|c|c|c|c|c|c|}
\hline \multirow[t]{2}{*}{ Variable } & \multirow[t]{2}{*}{ Categories } & \multicolumn{2}{|c|}{ Undernutrition } & \multirow{2}{*}{$\begin{array}{l}\text { Crude odds } \\
\text { ratio }(95 \% \mathrm{Cl})\end{array}$} & \multirow{2}{*}{$\begin{array}{l}\text { Adjusted odds } 9 \\
\text { ratio }(95 \% \mathrm{Cl})\end{array}$} \\
\hline & & Yes & No & & \\
\hline \multirow[t]{4}{*}{ Ethnicity } & Oromo & 54 & 81 & 1 & 1 \\
\hline & Amhara & 29 & 100 & $0.44(0.25-0.74)^{* *}$ & $1.13(0.39-3.27)$ \\
\hline & Tigre & 24 & 60 & $0.60(0.33-1.08)$ & $0.19(0.06-0.52)$ \\
\hline & Gurage & 25 & 56 & $0.67(0.37-1.20)$ & $0.02(0.01-0.17)$ \\
\hline \multirow[t]{3}{*}{ Religion } & Orthodox & 93 & 225 & 1 & 1 \\
\hline & Muslim & 18 & 57 & $0.76(0.43-1.38)$ & $0.60(0.21-1.73)$ \\
\hline & Protestant/Catholic or others & 30 & 36 & $2.01(1.17-3.46)^{*}$ & $1.75(0.74-4.18)$ \\
\hline \multirow[t]{3}{*}{ Family size } & $2-5$ & 100 & 207 & 1 & 1 \\
\hline & $6-8$ & 41 & 93 & $0.91(0.58-1.41)$ & $3.23(1.43-7.29)^{* *}$ \\
\hline & $>8$ & 7 & 18 & $0.81(0.34-6.52)$ & $2.13(0.97-8.91)$ \\
\hline \multirow[t]{2}{*}{ Child age } & $5-9$ & 39 & 138 & 1 & 1 \\
\hline & $10-14$ & 102 & 180 & $2.00(1.30-3.08)^{* *}$ & $1.31(0.65-2.66)$ \\
\hline \multirow[t]{2}{*}{ Child Sex } & Male & 88 & 169 & 1 & 1 \\
\hline & Female & 53 & 149 & $0.68(0.46-1.02)$ & $0.44(0.20-0.93)^{*}$ \\
\hline \multirow[t]{3}{*}{ Maternal age at child birth } & $<20$ & 40 & 38 & 1 & 1 \\
\hline & $20-30$ & 77 & 244 & $0.29(0.18-0.50)^{* * *}$ & $0.14(0.06-0.51)^{* * *}$ \\
\hline & $>30$ & 24 & 36 & $0.63(0.32-1.25)$ & $0.24(0.18-1.18)$ \\
\hline \multirow[t]{2}{*}{ Floor of the house } & Cement & 96 & 255 & 1 & 1 \\
\hline & Soil & 45 & 63 & $1.89(1.21-2.97)^{*}$ & $2.43(1.05-5.59)^{*}$ \\
\hline \multirow[t]{2}{*}{ Source of power for cooking } & Electric & 51 & 54 & 1 & 1 \\
\hline & Wood/Kerosene & 90 & 264 & $0.36(0.23-0.57)^{* * *}$ & $0.46(0.20-1.08)$ \\
\hline \multirow[t]{2}{*}{ Meal frequency in a day } & $>3$ & 56 & 169 & 1 & 1 \\
\hline & $\leq 3$ & 85 & 149 & $1.72(1.15-2.58)^{* *}$ & $1.77(1.23-2.55)^{* *}$ \\
\hline \multirow[t]{2}{*}{ Birth order } & $\leq 2$ & 84 & 237 & 1 & 1 \\
\hline & $>2$ & 57 & 81 & $1.99(1.30-3.02)^{* *}$ & $2.14(1.27-3.59)^{* *}$ \\
\hline
\end{tabular}

Note: ${ }^{*}=P<0.05,{ }^{* *}=P<0.01,{ }^{* * *}=P<0.001$.

$\boldsymbol{\eta}={ }^{=}$adjusted (from multivariate logistic regression model) for socio-economic and demographic characters of parents and children and health caring practices and environmental conditions (detail list available in the data analysis section), but only values of variables which showed significant association either in the bivariate or multivariate regression analysis were reported in the table. 
Table 4 Factors associated with stunting in school age children in Woreda 8 of Lideta sub-city, Addis Ababa, March, 2014

\begin{tabular}{|c|c|c|c|c|c|}
\hline \multirow[t]{2}{*}{ Variable } & \multirow[t]{2}{*}{ Categories } & \multicolumn{2}{|c|}{ Stunting } & \multirow{2}{*}{$\begin{array}{l}\text { Crude odds ratio } \\
(95 \% \mathrm{Cl})\end{array}$} & \multirow{2}{*}{$\begin{array}{l}\text { Adjusted odds ration } \\
(95 \% \mathrm{Cl})\end{array}$} \\
\hline & & Yes & No & & \\
\hline \multirow[t]{3}{*}{ Religion } & Orthodox & 54 & 264 & 1 & 1 \\
\hline & Muslim & 12 & 63 & $0.93(0.47-1.84)$ & $1.25(0.42-3.69)$ \\
\hline & Protestant/Catholic & 24 & 42 & $2.79(1.56-4.99)^{* *}$ & $3.29(1.15-9.39)^{*}$ \\
\hline \multirow[t]{3}{*}{ Maternal educational status } & No formal education & 18 & 61 & 1 & 1 \\
\hline & Primary & 19 & 172 & $0.37(0.18-0.76)^{* *}$ & $1.99(0.12-3.26)$ \\
\hline & Secondary and above & 53 & 131 & $1.37(0.74-2.54)$ & $6.96(2.94-16.46)$ \\
\hline \multirow{3}{*}{$\begin{array}{l}\text { Frequency of illness/infection in a year } \\
\text { prior to the study period } \square\end{array}$} & No infection & 12 & 90 & 1 & 1 \\
\hline & 1 & 18 & 96 & $1.41(0.64-3.08)$ & $0.07(0.01-0.46)$ \\
\hline & $>1$ & 60 & 183 & $2.46(1.26-4.80)^{* *}$ & $1.34(0.35-5.09)$ \\
\hline \multirow[t]{2}{*}{ Presence of dirt in finger } & Yes & 55 & 161 & 1 & 1 \\
\hline & No & 35 & 208 & $0.49(0.31-0.79)^{* *}$ & $0.2(0.37-1.18)$ \\
\hline \multirow[t]{2}{*}{ Floor material of the house } & Ceramic & 48 & 303 & 1 & 1 \\
\hline & Mud & 42 & 66 & $4.02(2.46-6.57)$ & $7.94(2.22,28.36)^{* * *}$ \\
\hline \multirow[t]{2}{*}{ Birth order } & $\leq 2$ & 51 & 270 & 1 & 1 \\
\hline & $>2$ & 39 & 99 & $2.09(1.29-3.36)^{*}$ & $5.43(2.62-11.25)^{* * *}$ \\
\hline \multirow[t]{3}{*}{ Maternal age } & $20-35$ & 39 & 228 & 1 & 1 \\
\hline & $36-45$ & 45 & 102 & $2.58(1.58-4.20)^{* * *}$ & $4.43(2.08-9.47)^{* * *}$ \\
\hline & $>45$ & 8 & 37 & $1.26(0.40-2.70)$ & $1.72(0.54-5.50)$ \\
\hline \multirow[t]{3}{*}{ Maternal age at child birth } & $<20$ & 19 & 59 & 1 & 1 \\
\hline & $20-30$ & 50 & 271 & $0.57(0.31-1.04)$ & $0.09(0.03-0.29)^{* * *}$ \\
\hline & $>30$ & 21 & 39 & $1.67(0.79-3.51)$ & $0.24(0.04-1.40)$ \\
\hline \multirow[t]{2}{*}{ Working status of mother } & House wife & 28 & 157 & 1 & 1 \\
\hline & Employed & 62 & 204 & $1.70(1.04-2.79)^{*}$ & $1.89(1.38-5.03)^{*}$ \\
\hline \multirow[t]{2}{*}{ Meal frequency in a day } & $>3$ & 26 & 199 & 1 & 1 \\
\hline & $\leq 3$ & 64 & 170 & $2.88(1.75-4.75)^{* * *}$ & $4.62(2.71-7.89)^{* * *}$ \\
\hline
\end{tabular}

Note: ${ }^{*}=\mathrm{P}<0.05,{ }^{*}=\mathrm{P}<0.01,{ }^{* * *}=\mathrm{P}<0.001$.

$\boldsymbol{\eta}=$ adjusted (from multivariate logistic regression model) for socio-economic and demographic characters of parents and children and health caring practices and environmental conditions (detail list available in the data analysis section), but only values of variables which showed significant association either in the bivariate or multivariate regression analysis were reported in the table.

$\square$ Illness/Infection: illnesses that enforces children to visit health centers/hospitals and take medication.

The higher prevalence of undrenutrition in children with higher birth orders (greater than two) compared to other children might be explained by the possibility that most Ethiopian parents give less attention, care and resource to older children when they give birth to new ones.

Children belonging to households with 6-8 members were more undernourished than those belonging to households with less than 6-8 members. Similar findings have been documented in other parts of the world $[14,28,29]$. A large number of household members could contribute to low levels of child care and dietary intake [30-32]. In line with this, undrenutrition was more common in children who had a meal frequency of at most 3 compared to those who had more than 3 per day. Stunting was more common in children living in houses with mud floor than in those living in the cement/brick/ceramic or wood floor, which is consistent with the study in Kenya [33]. The mud floor could indicate the poor socioeconomic status of the parents; this could contribute to the frequent undernutrition in the group. In addition, the mud floor surfaces could be conducive for the growth of pathogenic microorganisms which make children sick and undernourished [24].

One of the strongest determinants of stunting was the mother's occupation. Children having employed mothers were at greater risk of stunting than those having housewife mothers. This is similar with studies that reported increased prevalence of undernutrition among children whose mothers work outside of their home [34-36]. Mother' care plays a major role in child nutrition as she 
Table 5 Factors associated with underweight among school age children in district 8, Lideta sub-city, Addis Ababa, Ethiopia, March, 2014

\begin{tabular}{|c|c|c|c|c|c|}
\hline \multirow[t]{2}{*}{ Variable } & \multirow[t]{2}{*}{ Category } & \multicolumn{2}{|c|}{ Underweight } & \multirow{2}{*}{$\begin{array}{l}\text { Crude odds ratio } \\
(95 \% \mathrm{Cl})\end{array}$} & \multirow{2}{*}{$\begin{array}{l}\text { Adjusted odds ratio" } \\
(95 \% \mathrm{Cl})\end{array}$} \\
\hline & & Yes & No & & \\
\hline \multirow[t]{3}{*}{ Family size } & $2-5$ & 43 & 264 & 1 & 1 \\
\hline & $6-8$ & 29 & 105 & $1.65(0.98-2.78)$ & $2.82(1.45-5.48)^{* *}$ \\
\hline & $>8$ & 0 & 18 & NA & NA \\
\hline \multirow[t]{3}{*}{ Main decision maker } & Father & 49 & 155 & 1 & 1 \\
\hline & Mother & 10 & 72 & $0.44(0.21-0.92)^{*}$ & $0.39(0.16-0.94)^{*}$ \\
\hline & Both by discussion & 14 & 159 & $0.28(0.14-0.59)^{* * *}$ & $0.11(0.04-0.26)^{* * *}$ \\
\hline \multirow[t]{5}{*}{ Ethnicity of mother } & Oromo & 31 & 104 & 1 & 1 \\
\hline & Amhara & 11 & 118 & $0.31(0.15-0.65)^{* *}$ & $0.32(0.13-0.79)^{*}$ \\
\hline & Tigri & 21 & 63 & $0.12(0.59-2.11)$ & $1.72(0.77-3.74)$ \\
\hline & Gurage & 4 & 77 & $0.17(0.59-0.51)^{* *}$ & $0.12(0.04-0.42)^{* *}$ \\
\hline & Others & 6 & 24 & $0.84(0.47-1.43)$ & $0.29(0.08-1.12)$ \\
\hline \multirow[t]{2}{*}{ Maternal age } & $20-35$ & 49 & 221 & 1 & 1 \\
\hline & $>35$ & 25 & 164 & $0.69(0.43-1.27)$ & $0.38(0.15-0.97)^{*}$ \\
\hline \multirow[t]{2}{*}{ Maternal age at birth } & $<20$ & 25 & 53 & 1 & 1 \\
\hline & $\geq 20$ & 47 & 334 & $0.31(0.11-0.39)^{* * *}$ & $0.35(0.15-0.81)^{*}$ \\
\hline \multirow[t]{2}{*}{ Birth order } & $\leq 2$ & 59 & 238 & 1 & 1 \\
\hline & $>2$ & 39 & 123 & $1.28(0.74-1.98)$ & $2.85(1.35-6.02)^{* *}$ \\
\hline \multirow[t]{2}{*}{ Presence of hand washing facility } & Yes & 39 & 240 & 1 & 1 \\
\hline & No & 35 & 145 & $1.49(0.95-2.67)$ & $2.08(1.04-1.45)^{*}$ \\
\hline
\end{tabular}

Note: ${ }^{*}=\mathrm{P}<0.05,{ }^{* *}=\mathrm{P}<0.01,{ }^{* * *}=\mathrm{P}<0.001 \mathrm{NA}$ : not applicable

$\mathbf{q}=$ adjusted (from multivariate logistic regression model) for socio-economic and demographic characters of parents and children and health caring practices and environmental conditions (detail list available in the data analysis section), but only values of variables which showed significant association either in the bivariate or multivariate regression analysis were reported in the table.

is the closest to the child [37-39]. Thus, mothers who stayed at home could spend more time to care for their children.

Stunting was higher in children born to protestant or catholic mothers than to Orthodox or Muslim mothers. This could possibly result from differences in socioeconomics, exposure to infection and level of education. Further studies are needed to better understand why children with protestant or catholic mothers had a higher risk of undernutrition compared to children of orthodox religious mothers. The higher undernutrition risk in children born to mothers less than 20 years old could be due to low food intake by the mothers during pregnancy [40]. The low nutrient level of mothers, during pregnancy, could affect growth of the fetus and the baby during childhood [40]. In Ethiopia, undernutrition is higher in women 15 to 19 years old compared to women in the older ages [41]. In addition, women of less than 20 years of age are not usually employed and have less or no income to feed their children. Moreover, teenage pregnancy has been associated with adverse birth outcomes, including low birth weight and congenital malformations, that can later affect the nutritional status of the children $[42,43]$.
Parental education was not associated with undernutrition in the current study as previously reported [44-46]. Similarly, prevalence of undernutrition did not differ significantly among households having different incomes. Although educated mothers are aware of child nutrition, they could fail to practice it due to cultural, ethnic and religious reasons [47].

The current study is cross-sectional in design which does not establish causal relationship between undernutrition and the socioeconomic, socio-demographic, environmental and household factors. In addition, respondents could fail to provide correct responses to some of the questions and, hence, might introduce recall bias to the data. The numbers of male and female children were not matched and their pubertal stage was not considered in the study which could also have some effect on the outcome.

\section{Conclusions}

Undernutrition is prevalent among school age children living in Woreda 8, Lideta Sub-City, Addis Ababa, Ethiopia. Age, sex, birth order, daily meal frequency, maternal age and family size were major predictors of undernutrition in children. Employment, religious status of 
the mothers and floor type of child's house were also associated with the nutritional status of children. In addition to improving economic status of the community, policy makers should consider making greater provisions for health education regarding child nutrition. Nutritional screening and supplementary feeding programs to undernourished children are vital.

\section{Competing interests}

The authors declare that they have no competing interests.

\section{Authors' contributions}

DD, AD \& AA: Conceived and designed the study. DD: collected and analyzed the data. AD assisted data analysis. DD and AD drafted the manuscript. All authors read and approved the final manuscript.

\section{Acknowledgements}

We thank Debr Markos University and Gambi College of Health Science for giving financial support to conduct the study. We would also like to thank Werda 8 health extension workers for provision of information, facilities and support during data collection. We acknowledge Alnecia Rumphs of the Epidemiology Department, Robert Stemple College of Public Health, Florida International University for editing the language of the manuscript.

\section{Author details}

'Lia Foundation, 1695, Addis Ababa, Ethiopia. ${ }^{2}$ Aklilu Lemma Institute of Pathobiology, Addis Ababa University, 1176, Addis Ababa, Ethiopia. ${ }^{3}$ Department of Epidemiology, Robert Stempel College of Public Health and Social Work, Florida International University, Miami, FL, USA

Received: 25 August 2014 Accepted: 30 March 2015 Published online: 12 April 2015

\section{References}

1. De Onis M, Blössner M, Borghi E. Prevalence and trends of stunting among preschool children, 1990-2020. Public Health Nutr. 2012;15:142-8.

2. United nations system standing committee on nutrition: Report of the standing committee on nutrition at its thirty-third session. WHO; 2006. http://www.unscn.org/files/Annual_Sessions/33rd_SCN_Session/33rd_ session_REPORT.pdf. Retrieved February 22, 2015

3. Levels and trends in child mortality report 2011: Estimates developed by the an inter- agency group for child mortality estimation. http://www.childinfo.org/files/ Child_Mortality_Report_2011. Retrieved February 22, 2015.

4. Global Monitoring Report 2012: Food prices, nutrition, and the millennium development goals. http://go.worldbank.org/3LBH3GVIY0. Retrieved February 22, 2015

5. Kuczmarski RJ, Ogden CL, Guo SS, Grummer-Strawn LM, Flegal KM, Mei Z, et al. CDC Growth Charts for the United States: methods and development. Vital Health Stat. 2002;11:1-190.

6. Black R, Morris S, Jennifer B. Where and why are 10 million children dying every year? Lancet. 2003;361:2226-34.

7. Black RE, Allen LH, Bhutta ZA, Caulfield LE, de Onis M, Ezzati M, et al. Maternal and child undernutrition: global and regional exposures and health consequences. Lancet. 2008:371:243-60.

8. Rosalind SG, Yewelsew A, Hambidge KM, Isabel A, Aklilu T, Barbara JS. Inadequate feeding practices and impaired growth among children from subsistence farming households in Sidama, Southern Ethiopia. Matern Child Nutr. 2009:5:260-75.

9. Bain LE, Awah PK, Geraldine N, Kindong NP, Sigal Y, Bernard N, et al. Malnutrition in Sub-Saharan Africa: burden, causes and prospects. Pan Afr Med J. 2013;15:120

10. Zerfu M, Mekasha A. Anthropometric assessment of school age children in Addis Ababa. Ethiop J Health Dev. 2006:44(4):347-52.

11. Daniel WW. Biostatistics: a foundation for analysis in the health sciences. London, United Kingdom: Wiley; 2009.

12. World Health Organization. Anthro plus for personal computers manual: software for assessing growth of the world's children and adolescent. Geneva: WHO; 2009
13. World Health Organization. Child growth standards: length/height-for-age, weight-for-age, weight-for-length, weight-for height and body mass indexforage. Methods and development. Geneva: WHO; 2006.

14. Herrador Z, Sordo L, Gadisa E, Moreno J, Nieto J, Benito A, et al. Cross-sectional study of malnutrition and associated factors among school aged children in rural and urban settings of Fogera and Libo Kemkem districts. Ethiopia Plose One. 2014;9(9), e105880.

15. Degarege A, Erko B. Association between intestinal helminth infections and underweight among school children in Tikur Wuha Elementary School, Northwestern Ethiopia. J Infect Public Health. 2013;6:125-33.

16. Nguyen NL, Gelaye B, Aboset N, Kumie A, Williams MA, Berhane Y. Intestinal parasitic infection and nutritional status among school children in Angolela. Ethiopia J Prev Med Hyg. 2012;53(3):157-64

17. Mekonnen $\mathrm{H}$, Tadesse T, Kisi T. Malnutrition and its correlates among rural primary school children of Fogera district. Northwest Ethiopia J Nutr Disorders Ther. 2013;S12:002.

18. Reji P, Belay G, Erko B, Legesse M, Belay M. Intestinal parasitic infections and malnutrition amongst first-cycle primary schoolchildren in Adama, Ethiopia. Afr J Prm Health Care Fam Med. 2011;3(1):198-203.

19. Parraga I. Gender differences in growth of school-age children with schistosomiasis and geohelminth infection. Am J Trop Med Hyg. 2000;55:150-6.

20. Francis L, Kirunda B, Orach CG. Intestinal helminth infections and nutritional status of children attending primary schools in Wakiso District, Central Uganda. Int J Environ Res Public Health. 2012;9:2910-21.

21. Genebo T, Girma W, Hadir J, Demmissie T. The association of children's nutritional status to maternal education in Ziggbaboto, Guragie Zone South Ethiopia. Ethiop J Health Dev. 1999;13(1):55-61.

22. Yimer G. Malnutrition among children in southern Ethiopia: levels and risk factors. Ethiop J Health Dev. 2000;14(3):283-92.

23. Samson $T$, Lakech $\mathrm{G}$. Malnutrition and enteric parasites among under five children in Aynalem village. Tigray Ethiop J Health Dev. 2000;14(1):67-75.

24. Katona $\mathrm{P}$, Katona-Apte J. The interaction between nutrition and infection. Clin Infect Dis. 2008:46:1582-8.

25. Gandhi SJ, Godara N, Modi A, Kantharia S. Impact of feeding practices on nutritional status of children in rural area of Navsari district. Int J Med Sci Public Health. 2014;3(11):1338-42.

26. Dennison BA, Erb TA, Jenkins PL. Television viewing and television in bedroom associated with overweight risk among low - income preschool children. Pediatrics. 2002;109:1028-35.

27. Dietz WHJ, Gortmaker SL. Do we fatten our children at the television set? Obesity and television viewing in children and adolescents. Pediatrics. 1985;75:807-12.

28. Novella R. Parental education, gender preferences and child nutritional status: evidence from four developing countries. No 2013-06, ISER Working Paper Series. https://www.iser.essex.ac.uk/research/publications/workingpapers/iser/2013-06. Retrieved February 22, 2015

29. Elkholy TA, Hassanen NHM, Rasha MSC. Demographic, socio-economic factors and physical activity affecting the nutritional status of young children under five years. J Am Sci. 2011;7:1-12. ISSN 1545-1003.

30. Khan Khattak MMA, Ali S. Malnutrition and associated factors in pre-school children (2-5 years) in district Swabi (NWFP) -Pakistan. J Med Sci. 2010;10(2):34-9.

31. Booth $A L$, Joo Kee $H$. Birth order matters: the effect of family size and birth order on educational attainment. IZA DP No. 1713, August 2005. http:// ftp.iza.org/dp1713.pdf. Retrieved February 22, 2015

32. Maseta E, Kogi-Makau W, Omwega AM. Childcare practices and nutritional status of children aged 6-36 months among short- and long-term beneficiaries of the Child Sunvival Protection and Development Programmes (the case of Morogoro, Tanzania). S Afr J Clin Nutr. 2008;21(1):16-20.

33. Filmer D, Friedman J, Schady N. Development, modernization, and childbearing: the role of family sex composition. World Bank Econ Rev. 2009;23:371-98.

34. Grace K, Davenport F, Funk C, Lerner AM. Child malnutrition and climate in Sub-Saharan Africa: an analysis of recent trends in Kenya. App Geog 2012:35:405-13.

35. Ndukwu Cl, Egbuonu I, Ulasi TO, Ebenebe JC. Determinants of under nutrition among primary school children residing in slum areas of a Nigerian city. Niger J Clin Pract. 2013;16:178-83.

36. Abbi R, Christian P, Gujral S, Gopaldas T. The impact of maternal work on the nutrition and health status of children. Food Nutr Bull. 1991:13(1):20-4. 
37. Popkin BM. Time allocation of the mother and child nutrition. Ecol Food Nutr. 1980;9:1-14.

38. Amugsi DA, Mittelmark MB, Lartey A, Matanda DJ, Urke HB. Influence of childcare practices on nutritional status of Ghanaian children: a regression analysis of the Ghana Demographic and Health Surveys. BMJ Open. 2014;4, e005340.

39. Bolajoko OO, Ogundahunsi GA. The effect of child care and feeding practices on the nutritional status of children of market women in Ondo State, Nigeria. IOSR J Pharm Bio Sci. 2012;1:22-4.

40. Ruel MT, Levin C, Armar-Klemesu M, Maxwell D, Morris SS. Good care practices can mitigate the negative effects of poverty and low maternal schooling on children's nutritional status: evidence from Accra, Ghana. Food consumption and nutrition division discussion paper 62. Washington DC: International Food Policy Research Institute; 1999.

41. Woldemariam G, Genebo T. Determinants of nutritional status of women and children in Ethiopia. Calverton. Maryland, USA: ORC Macro; 2002.

42. Central Statistical Agency [Ethiopia] and ICF International. Ethiopia demographic and health survey 2011. Addis Ababa, Ethiopia and Calverton, Maryland, USA.

43. Gilbert W, Jandial D, Field N, Bigelow P, Danielsen B. Birth outcomes in teenage pregnancies. J Matern Fetal Neonatal Med. 2004;16:265-70.

44. Chen XK, Wen SW, Fleming N, Demissie K, Rhoads GG, Walker M. Teenage pregnancy and adverse birth outcomes: a large population based retrospective cohort study. Int J Epidemiol. 2007;36(2):368-73.

45. Rayhan MI, Khan SH. Factors causing malnutrition among under five children in Bangladesh. Pakistan J Nut. 2006;5:558-62.

46. Getaneh T, Assefa A, Tadesse Z. Protein-energy malnutrition in urban children: prevalence and determinants. Ethiop Med J. 1998:36:153-65.

47. Al-Mekhlafi HM, Azlin M, Nor Aini U, Shaik A, Sa'iah A, Fatmah MS, et al. Giardiasis as a predictor of childhood malnutrition in Orang Asli children in Malaysia. Trans R Soc Trop Med Hyg. 2005;99:686-91.

\section{Submit your next manuscript to BioMed Central and take full advantage of:}

- Convenient online submission

- Thorough peer review

- No space constraints or color figure charges

- Immediate publication on acceptance

- Inclusion in PubMed, CAS, Scopus and Google Scholar

- Research which is freely available for redistribution 